(Departamento de Zoologia da Universidade de S. Paulo. Prof. E. MARCUS)

\title{
Diminuição rítmica do volume nuclear do figado e do pancreas nos girinos de anuros
}

POR

\author{
G. Schreiber e M. Romano Schreiber
}

I NDICE

1) INTRODUÇÃO

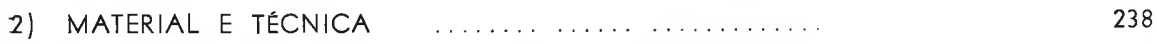

3) VOLUMES NUCLEARES E MORFOLOGIA EPÁTICA $\quad \ldots \ldots .244$

4) VOLUMES NUCLEARES E MORFOLOGIA PANCREÁTICA $\ldots \ldots \ldots \ldots . . .247$

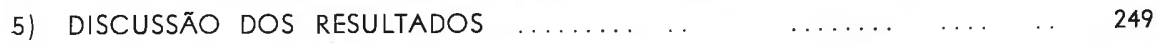

a) Diminuição rítmica e problema das sub-classes intermediárias ..... 249

b) Problemas inerentes às mitoses e à amplitude de variabilidade nuclear 252

c) Diferenciação citológica e crescimento geral do fígado ......... 257

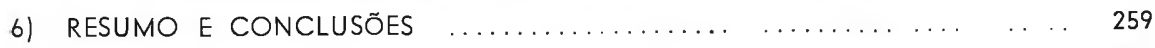

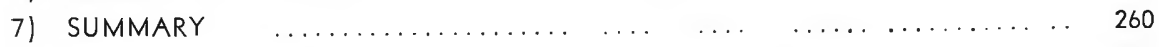

8) BIBLIOGRAFIA $\ldots \ldots \ldots \ldots \ldots \ldots \ldots \ldots 2$

\section{1) Introdução}

Numerosas pesquizas efetuadas sobretudo em Mamíferos, ilustraram o comportamento biométrico das células de alguns tecidos, quer durante o desenvolvimento, quer em condições fisiológicas e patológicas diferentes.

Foi estabelecido que o volume médio do núcleo das células aumenta descontinuamente, em alguns tecidos, durante a vida do indivíduo, de conformidade com uma série de valores que estão entre si nas relações 1:2:4:8.

Estes estudos, iniciados por Heidenhain e Jakobi, foram mais tarde continuados por numerosos pesquizadores, tanto sobre as células epáticas como sobre outras células (Clara, Hertwig. Wermel e sua escola, etc.). 
De tais investigações resulta que nas células de alguns tecidos se dá uma duplicação do volume nuclear que pode ser ou não seguida pela própria divisão nuclear. Se tal divisão se der, teremos células binucleadas, ao passo que se ela não se verificar, teremos células com volume nuclear duplo em relação ao anterior. Max Clara (1931) baseando-se na interpretação dessa duplicação (estabelecida primeiramente por Heidenhain: "Protomerentheorie") adota o nome de "fenósquise" nos casos em que divisões mitóticas levam à duplicação da massa nuclear com consequente repartição dessa em dois núcleos filhos, e denomina "endósquise" os casos em que a duplicação da massa nuclear não é seguida pela divisão e em que se chega, portanto, à formação de um único núcleo com volume duplo, situado dentro de uma célula com volume tambêm duplo.

As células que apresentam esses fenômenos de crescimento descontínuo por sucessivas duplicações do volume, pertencem à categoria dos "elementos estáveis" da classificação de Levi e Bizzozzero (*).

$\mathrm{Na}$ rica literatura sobre este assunto, posterior aos trabalhos clássicos já mencionados, foram descritos vários casos de variação rítmica dos volumes nucleares. Nessas pesquizas, porém, a interpretação de Heidenhain-Jakobi de uma duplicação do patrimônio nuclear em calda aumento sucessivo, nem sempre foi aceita, tendo, de fato, sido observados valores diferentes de 2 (Wermel e sua escola) nas relações entre os sucessivos tamanhos nucleares. Brummelkamp (1939) examinou os casos em que tinham sido encontrados valores intermediários entre 1 e 2 e verificou que todos os casos apresentavam seus valores dispostos segundo uma série geométrica cujo módulo é $\sqrt{2}(1,41)$, sendo pequenas as flutuações ao redor deste valor. Isto é válido tanto quando se consideram os valores nucleares durante o crescimento de uma única espécie, como quando se levam em conta os de espécies diferentes afins, como, por fim, quando se consideram os de um mesmo tecido em condições normais e patológicas. Brummelkamp mantendo como base a

$\left({ }^{*}\right)$ Como se sabe, de acordo com esta classificação os tecidos do organismo podem ser divididos em 3 categorias: tecidos com elementos lábeisi estáveis e permanentes. Na primeira compreendem-se os tecidos cujas células se reproduzem mesmo depois de se ter completado a crescimento do organismo e que, além disso, apresentam um tamanho constante (epitélios, glândulas intestinais, sebáceas, sângue, linfa).

Nos tecidos com elementos estáveis somente uma parte das células conserva, no adulto, a capacidade reprodutora, as demais crescem em idades sucessivas. Como vimos, esse crescimento é muitas vezes rítmico (fígado, pâncreas, rim, etc.).

Nos tecidos com elementos permanentes todas as células não se multiplicam mais depois de sua diferenciação embrionária e crescem proporcionalmente ao crescimento corpúsreo (cel. nervosas). 
interpretação da duplicação nuclear de Heidenhain-Jakobi, tenta explicar o significado das formas intermediárias $(\sqrt{ } 2)$ baseando-se em pesquizas da variação do volume nuclear e plasmático durante a intercinese (Popoff em Frontonia, Bock, Dubois, Brummelkamp sobre o crescimento das células nervosas).

Tambêm G. Hertwig, ao estudar alguns casos de volumes intermediários entre 1 e 2, achou a relação $1: 1.4 \mid(\sqrt{2})$ e esboçou uma interpretação da natureza destas classes intermediárias admitindo que o número de cromosomas nesse caso é proporcional à superfície e não ao volume do núcleo. Ele mesmo reconhece, porém, a possibilidade da existência de outras interpretações.

Algumas pesquizas sobre outro material evidenciaram que a variação do volume nuclear pode dar-se de modo descontínuo tambêm em série descendente: entre outras merecem especial atenção aquelas sobre o tamanho nuclear da série espermatogenética e na segmentação, consideradas como o resultado de successivas divisões não separadas por um período de crescimento. ("Multiple Succedantheilungen" de G. Hertwig).

$\mathrm{Na}$ série espermatogenética este fato foi salientado por vários autores (Heidenhain, Jakobi, G. Hertwig, B. Schreiber). G. Hertwig tratou difusamente dessas questões num trabalho publicado em 1933, discutindo também o problema teórico do significado dessa redução: em algumas espécies animais foi provada, por meio de pesquizas cariométricas, a existencia indicustivel de uma terceira divisão de maturação na linhagem masculina.

Outros casos de redução rítmica do volume nuclear foram descritos por Jakobi na ontogénese dos eritroblastos e dos timocitos, por Freerksen (citado por G. Hertwig e por Wermel) tambêm nos eritroblastos; Keller relata uma redução nuclear do fígado do embrião de galinha durante a ontogénese, sendo esse fato tambêm verificado por Binda (dados relatados por B. Schreiber) na galinha. M. Clara demonstrou a existência de uma diminuição nuclear nas células intersticiais do testículo durante a velhice, relacionada, neste caso, com um aumento numérico das células binucleadas.

Tambêm Silvestroni encontrou alguns casos de redução volumétrica nuclear na suprarenal de mamíferos.

Recente pesquiza de B. Schreiber e Angeletti, contribuiu novamente para o conhecimento do fenômeno da variação do volume nuclear ilurante o desenvolvimento. Estes autores estudaram as curvas de variabilidade do volume nuclear epático durante o desenvolvimento da Carpa, desde a eclosão até $\circ$ estado adulto, acharam que o desenvolvimento do animal pode ser dividido em dois períodos nitidamente distintos: no primeiro, que vae desde a eclosão até o animal apresentar o comprimento de $40 \mathrm{~mm}$., os valores nucleares apresentam curvas unimodais, nos estadios sucessivos esses valores 
diminuem descontinuamente apresentando os dados na proporção 4:2:1. Alcançado esse valor mínimo, no período seguinte os valores volumétricos aumentam, sempre descontinuamente, e as curvas apresentam vários máximos correspondentes à bluplicações sucessivas do volume nuclear. No $1 .{ }^{\circ}$ período, por ocasião da redução do volume, os autores verificaram a presença de mitoses em $3 \%$ das células. $\bigcirc 2{ }^{\circ}$ período, pelo contrário, coincide com a diferenciação funcional da célula epática que caminha pari e passu com o crescimento rítmico nuclear. Tal fato já fora verificado por Fischer no epitélio folicular do Piolho.

Nas pesquizas presentes quizemos retomar o estudo desse problema sobre Anfíbios Anuros, nos quais foram relativamente escassas as pesquizas. Entre os Autores que abordaram o assunto, mencionaremos: Jakobi que estudou os tamanhos nucleares epáticos de Proteus; Sauser em Proteus, Triton teniatus e T. cristatus; Wermel e Jgnatiewa que verificaram ser na Rã a média dos tamanhos nucleares epáticos do girino maior do que a do adulto e na Rana temporaria a presença de 3 classes diferentes de volumes nucleares. Além disso, Woss (citado por Müller) pesquizou os núcleos das diferentes zonas do fígado das larvas de Salamandra. Niero verificou em Proteus e Triton curvas constantemente unimodais asimétricas do lado direito (lado em que se acham os valores mais altos) delduzindo desse fato a existência de um crescimento lento mas não descontínuo. Pela observação de algumas de suas curvas a sua conclusão parece-nos um pouco prematura e talvez ulterior elaboração dos dados levar-nos-ia a conclusões diferentes.

Tendo precedentemente estudado a metamorfose de Bufo sob vários pontos de vista, achamos interessante relacionar os fenômenos da variação volumétrica do núcleo epático com as fases do desenvolvimento e da metamorfose deste animal, tendo sobretudo presente a profunda crise que o período da metamorfose representa na ontogénese deste animal.

É-nos grato espressar aqui o nosso mais vivo reconhecimento pela hospitalidade recobida durante a presente pesquiza, ao Departamento de Zoologia da Faculdade de Filosofia, Ciências e Letras e por todas as gentilezas que nos foram dispensadas pelo Prof. E. Marcus e pelo Prof. P Sawaya, assim como ao Dr. J. de Paiva Carvalho do Dep. De Industria Animal cujo interesse permitiu-nos extender nossas observações sobre o material de Rana catesbiana.

Dirigimos também vivos agradecimentos ao Prof. L. Galvani da Universidade de São Paulo, pelos valiosos conselhos que nos forneceu na elaboração da parte estatística do trabalho. 


\section{2) Material e Técnica}

Para tais pesquizas usámos uma série de 17 estadios de Bufo vulgaris desde $\circ 10^{\circ}$ dia após a eclosão até findar a metamorfose, preparados no Instituto Zoológico da Universidalde de Padua, entre 1936-37 e já utilizados numa série precedente de trabalhos sobre a metamorfose normal e acelerada. Citamos tais trabalhos (G. Schreiber, M. Romano, G. Schreiber e C. Koch) para os pormenores de técnica, criação, tiroidização experimental, etc.

E' suficiente notar aqui que todos os exemplares foram fixados em Bouin e preparados em parafina, coloridos com Hematoxilina Heidenhain, Ehrlich e Carazzi.

Foram desenhados na câmara clara pelo menos 100 núcleos epáticos e 100 pancreáticos de cada estadio, com o aumento de 1500 diâmetros, e foram medidos sobre o desenho os diâmetros das esferas circunscritas, sendo calculado o valor nuclear $\left(d^{3} / 1,91\right)$. Em alguns casos em que as curvas não pareciam muito nítidas, mediram-se 150 a 200 núcleos. Essas medidas foram tomardas indiferentemente em todas as regiões do fígado: parece-nos importante acentuar este fato visto que, sobretudo em Mamíferos, vários autores frisaram a distribuição não homogênea das várias classes volumétricas nas diferentes regiões do lóbulo epático. Tambêm nos Urodelos, Niero achou distribuição desigual dos núcleos de volume diferente (estando os maiores situados na periferia e em volta dos vasos). As nossas medidas referem-se, portanto, ao fígado como um toldo.

Os valores nucleares assim obtidos, foram reunidos em classes segundo - diâmetro e assim diagramados, obtendo-se as curvas de frequência. Os dados relativos são reunidos nas tabelas I e II nos gráficos Fig. I e 2.

TABELA I

FIGADO

\begin{tabular}{|c|c|c|c|c|c|c|c|c|c|c|c|c|c|c|c|}
\hline \multirow{2}{*}{$\begin{array}{l}\text { N.o } \\
\text { prot. }\end{array}$} & \multirow[t]{2}{*}{ idade } & $\bar{d}$ & 7 & 8 & 9 & 10 & 11 & 12 & 13 & 14 & 15 & 16 & 17 & 18 & 19 \\
\hline & & $\mathrm{v}$ & 179 & 268 & 381 & 523 & 696 & 904 & 1150 & \multicolumn{2}{|c|}{$|1436| 1767$} & 2144 & 2570 & 3053 & 3591 \\
\hline 72 & $10 \mathrm{dia}$ & & & & 1 & 1 & 10 & 18 & 32 & 43 & 47 & 26 & 11 & 5 & 1 \\
\hline 24 & $14 »$ & & & & & & 3 & 12 & 24 & 20 & 21 & 9 & 3 & & \\
\hline 50 & $29 »$ & & & & 3 & 7 & 20 & 33 & 23 & 11 & 1 & & & & \\
\hline 51 & $51 »$ & & & & 1 & 17 & 32 & 37 & 10 & 3 & & 1 & & & \\
\hline 139 & $72\left(1^{\circ}\right.$ & & & & & 11 & 24 & 35 & 19 & 9 & 2 & & & & \\
\hline 47 & $77\left(1^{0}\right.$ & & & & & 10 & 41 & 40 & 0 & 3 & & & & & \\
\hline 27 & $80\left(1^{0}\right.$ & & & & 1 & 14 & 22 & 30 & 18 & 10 & 6 & & & & \\
\hline II ${ }^{\circ}$ & $\mathrm{Il}$ & & & 4 & 12 & 36 & 31 & 13 & 3 & 1 & 1 & & & & \\
\hline IIIo & III & & & & 5 & 38 & 40 & 15 & 2 & 2 & 1 & & & & \\
\hline Vo & V & & & 5 & 23 & 42 & 24 & 1. & 3 & 1 & & & & & \\
\hline VIo & VI & & 1 & 2 & 13 & 36 & 24 & 14 & 4 & & & & & & \\
\hline VIIo & VII & & & 6 & 44 & 46 & $\begin{array}{r}9 \\
9\end{array}$ & 4 & & & & & & & \\
\hline 31 & VIII & & & 7 & 20 & 52 & 19 & 7 & & & & & & & \\
\hline 52 & VIII & & 1 & 10 & 28 & 41 & 14 & 5 & & & & & & & \\
\hline
\end{tabular}


PÂNCREAS

\begin{tabular}{|c|c|c|c|c|c|c|c|c|c|c|c|c|c|c|}
\hline N.o & idade $\mathrm{d}$ & 8 & 9 & 10 & 11 & 12 & 13 & 14 & 15 & 16 & 17 & 18 & 19 & 20 \\
\hline prot. & $\bar{v}$ & 268 & 381 & 523 & 696 & 904 & 1150 & 1436 & 1767 & 2144 & 2570 & $3^{\prime \prime} 53$ & 3591 & 4188 \\
\hline 72 & 10 dias & & & 1 & 3 & 4 & 16 & 17 & 24 & 12 & 12 & 4 & & \\
\hline 24 & $14 \ll$ & & & 1 & 6 & 27 & 37 & 28 & 34 & 13 & 5 & & & \\
\hline 50 & 29 & & & 3 & 32 & 35 & 16 & 17 & 6 & 1 & & & & \\
\hline 139 & $72\left(1^{0}\right)$ & & & 2 & 13 & 25 & 20 & 13 & 9 & 7 & 2 & 1 & & 2 \\
\hline 47 & $1^{0}$ & & & 2 & 21 & 23 & 18 & 13 & 21 & 4 & 3 & & & 1 \\
\hline 27 & $1^{0}$ & & & 1 & 19 & 27 & 24 & 17 & 11 & 4 & & 1 & & \\
\hline II 0 & İ 0 & & 11 & 56 & 28 & 6 & 5 & 1 & & & & & & \\
\hline IVo & IV0 & & 18 & 53 & 22 & 3 & 1 & 2 & 1 & & & & & \\
\hline 31 & VIII0 & 5 & 27 & 49 & 16 & 5 & 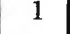 & & & & & & & \\
\hline
\end{tabular}

Os valores modais destes dados foram determinaidos pelo processo gráfico e são representados na tabela III. Os diagramas I e 2 correspondentes respetivamente ao fígado e ao pâncreas, representam os polígonos de fre-

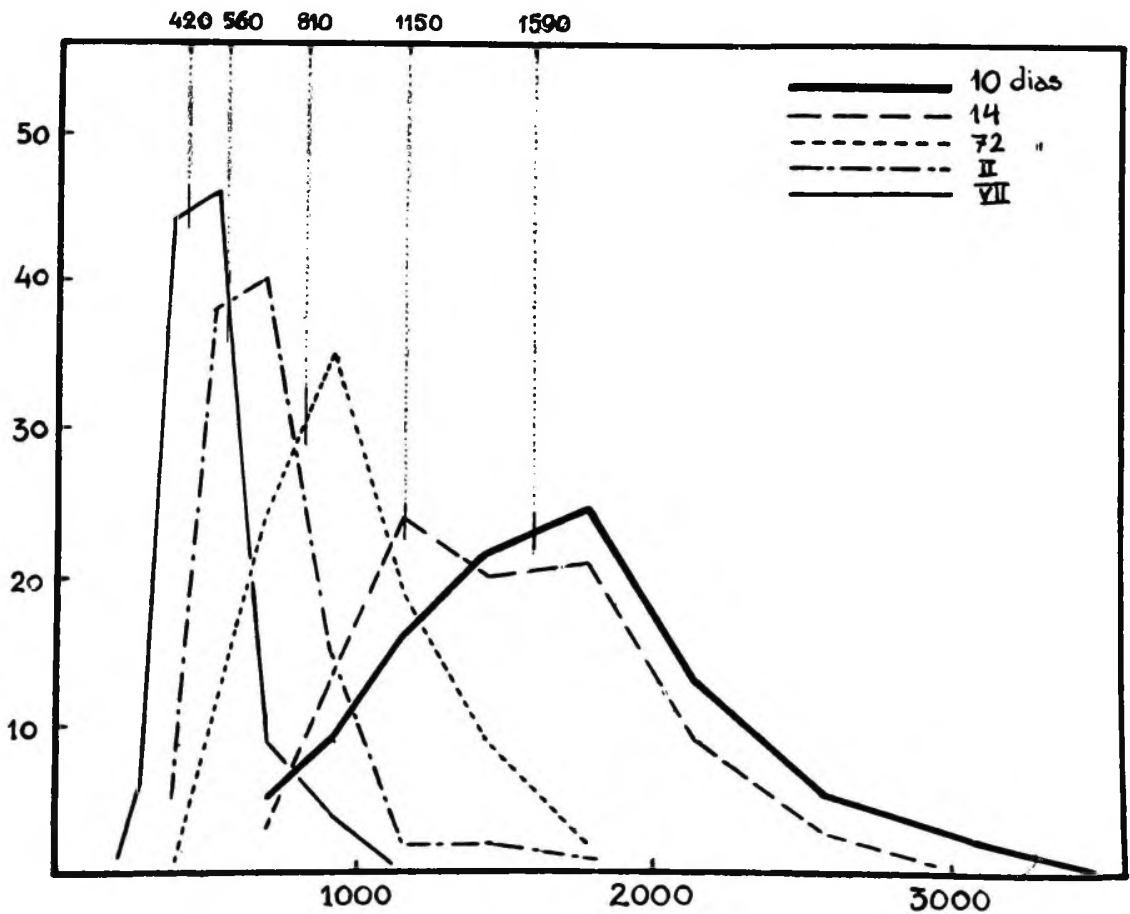

Fiy. I

Curvas de frequência dos volumes nucleares do fígado, nos $10^{\circ}, 14^{\circ}, 72 .^{\prime}$ dias, Il e VII estadios da metamorfose. No eixo das abcissas superiores foram indicados os valores das modas 


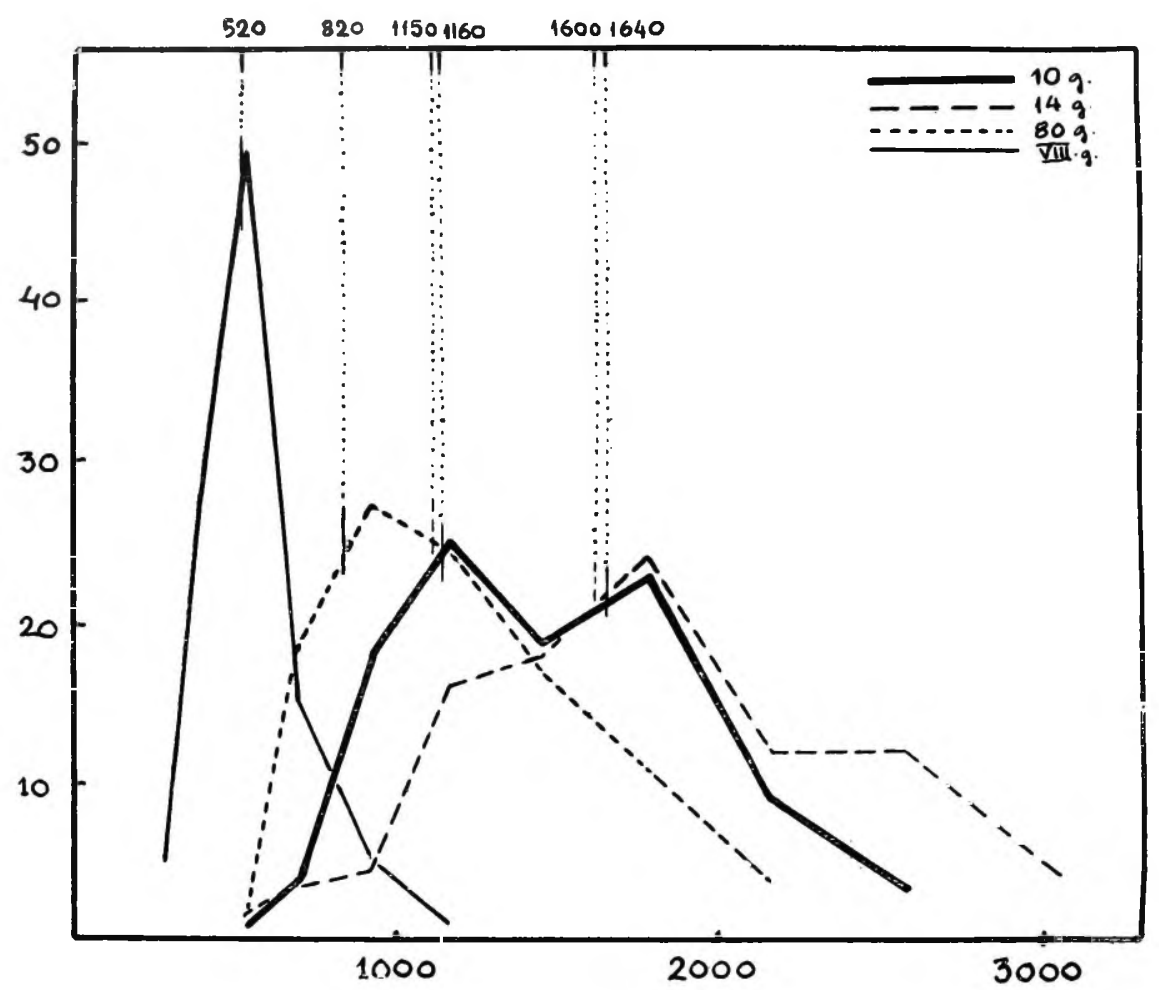

Fig. 2

Curvas de frequência dos volumes nucleares do pâncreas, nos $100^{\circ}, 144^{\circ} 800^{\circ}$ dias e no VIII estadio da metamorfose. No eixo da abcissa superior foram indicados os valores das modas

quência de alguns dos estadios estudados. Para tornar o desenho mais claro não desenhamos o polígono de todos os estadios, mas somente um de cada fase do desenvolvimento. Na fig. 3 e 4 representamos o fenômeno da diminuição rítmica dos volumes, marcando em abcissas os estadios do desenvolvimento (designados em dias, e, durante a metamorfose, pela comparação com os estadios "padrões") e em orldenadas os valores modais de cada estadio. Representamos, além disso, numa linha pontuada horizontal o valor médio dessas modas o que indica o nivel dos valores volumétricos típicos de cada estadio.

Nos seus traços gerais os fenômenos aqui descritos se apresentam mais simples e acentuados no fígado e menos no pâncreas no qual a variabilidade é maior e onde aparecem em certos estadios, mais de um máximo de frequência. Devido a este fato, na Fig. 4, nos casos em que se apresentam 
DIMINUIÇÃO RITMICA DO VOLUME NUCLEAR DO FIGADO E DO PANCREAS 24I

TABELA III

VALORES MODAIS (REAIS E TENDENCIAIS)

\begin{tabular}{|c|c|c|c|c|c|c|c|c|c|c|c|}
\hline \multirow{2}{*}{$\begin{array}{c}\text { Esta- } \\
\text { dios }\end{array}$} & \multicolumn{5}{|c|}{$\overline{\text { Figa do }}$} & \multicolumn{6}{|c|}{ Pâncreas } \\
\hline & V. 5 & V. 4 & v. 3 & V. 2 & V. 1 & V 6 & V. 5 & V 4 & V. 3 & $\mathrm{~V} 2$ & V 1 \\
\hline $\begin{array}{r}0 \\
14 \\
29 \\
51 \\
72 \\
77 \\
80 \\
\text { II0 } \\
\text { III0 } \\
\text { IV0 } \\
\text { V0 } \\
\text { VI0 } \\
\text { VII0 } \\
\text { VIII0 } \\
\text { VIII0 }\end{array}$ & $\begin{array}{c}1590 \\
(1600)\end{array}$ & 1150 & $\begin{array}{l}790 \\
790 \\
810 \\
810 \\
820\end{array}$ & $\begin{array}{l}540 \\
560 \\
\\
540 \\
560 \\
\\
520 \\
530\end{array}$ & 420 & $(2000-2500)$ & $\begin{array}{c}1640 \\
(1640) \\
1700\end{array}$ & $\begin{array}{c}1160 \\
1080 \\
(1200) \\
\\
(1100) \\
(1150) \\
(1150) \\
(1150)\end{array}$ & $\begin{array}{c}(800) \\
800 \\
\\
800 \\
780 \\
800\end{array}$ & $\begin{array}{r}525 \\
525 \\
\\
525\end{array}$ & \\
\hline
\end{tabular}

TABELA IV

COMPARAÇÃo ENTRE A SÉRIE $\overline{\text { V2}}$ (Brummelkamp) E A SÉRIE CONSTRUIDA COM AS MÉdIAS DOS VALORES MODAIS DO FÍGADO

\begin{tabular}{|c|c|c|c|}
\hline Estadios & $\begin{array}{c}\text { médias das } \\
\text { modas }\end{array}$ & $\begin{array}{c}\text { série } \mathrm{V} \overline{2} \\
\text { (Brummelkamp) }\end{array}$ & $\begin{array}{c}\text { afastamento dos modulo } \\
\text { em relação a V } \frac{2}{2}\end{array}$ \\
\hline $10 \mathrm{~d}$ & 420 & 400 & $0,93 . \mathrm{V} \overline{\frac{2}{2}}$ \\
$14 \mathrm{~d}$ & 550 & 564 & $1,04 . \mathrm{V} \frac{\overline{2}}{1,01 . \mathrm{V}}$ \\
m-89 d & 810 & 800 & $0,98 . \mathrm{V} \frac{2}{2}$ \\
fim da & 1150 & 1128 & \\
metam. & 1590 & 1600 & \\
\hline
\end{tabular}




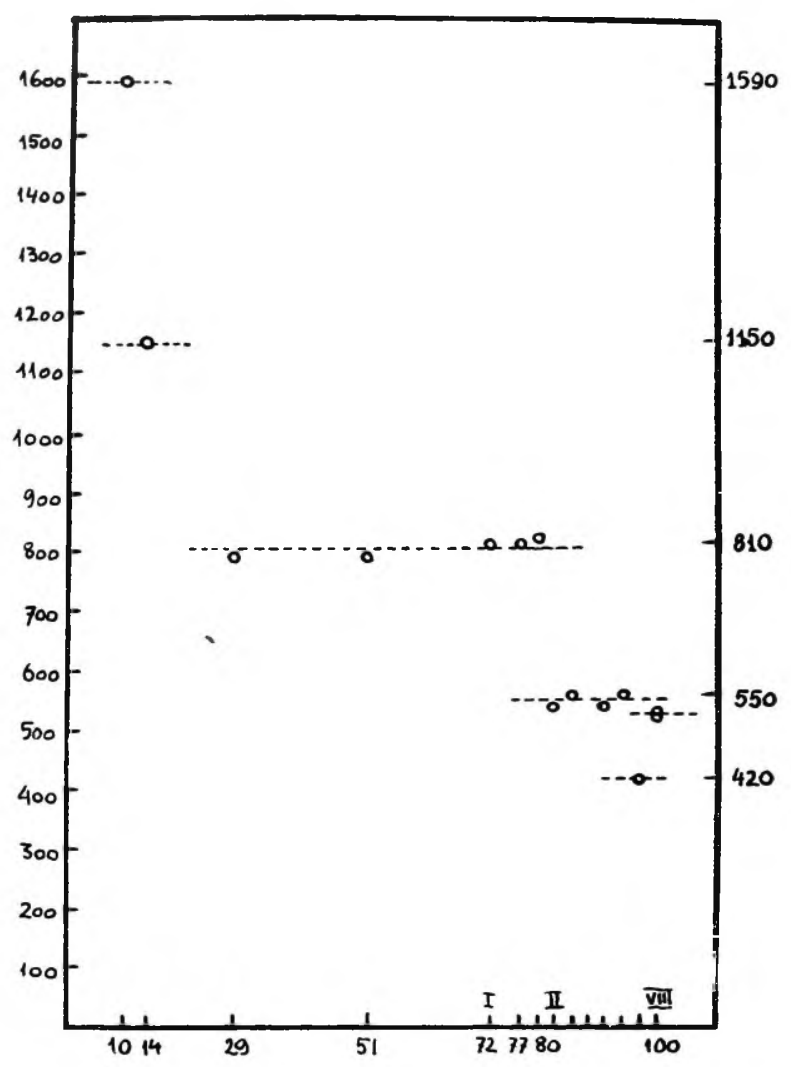

Fig. 3

Diagrama dos valores modais dos volumes nucleares do Fígado em cada estadio do desenvolvimento.

Em ordenadas: à esquerda escala dos valores modais; à direịta válores médios das modas dé cada grupo de estadios.

Em abcissas: Idade dos girinos medida em dias a partir da eclosão até o início da metamorfose, depois desta pelos 8 esładios "padrões".

dois valores modais, representamo-los reunidos por uma linha vertical pontuada.

Em alguns casos, nas curvas calculadas teoricamente, aparecem algumas flexões que indicam a tendência à formação de um segundo máximo. $\mathrm{Na}$ III tabela puzemos os valores volumétricos correspondentes a esses valores modais secundários, entre parênteses. 
Quando ha várias modas ou quando ha valores que tendem a constituir uma segunda moda, êles correspondem mais ou menos exatamente aos valores da série teórica que escolhemos como base.

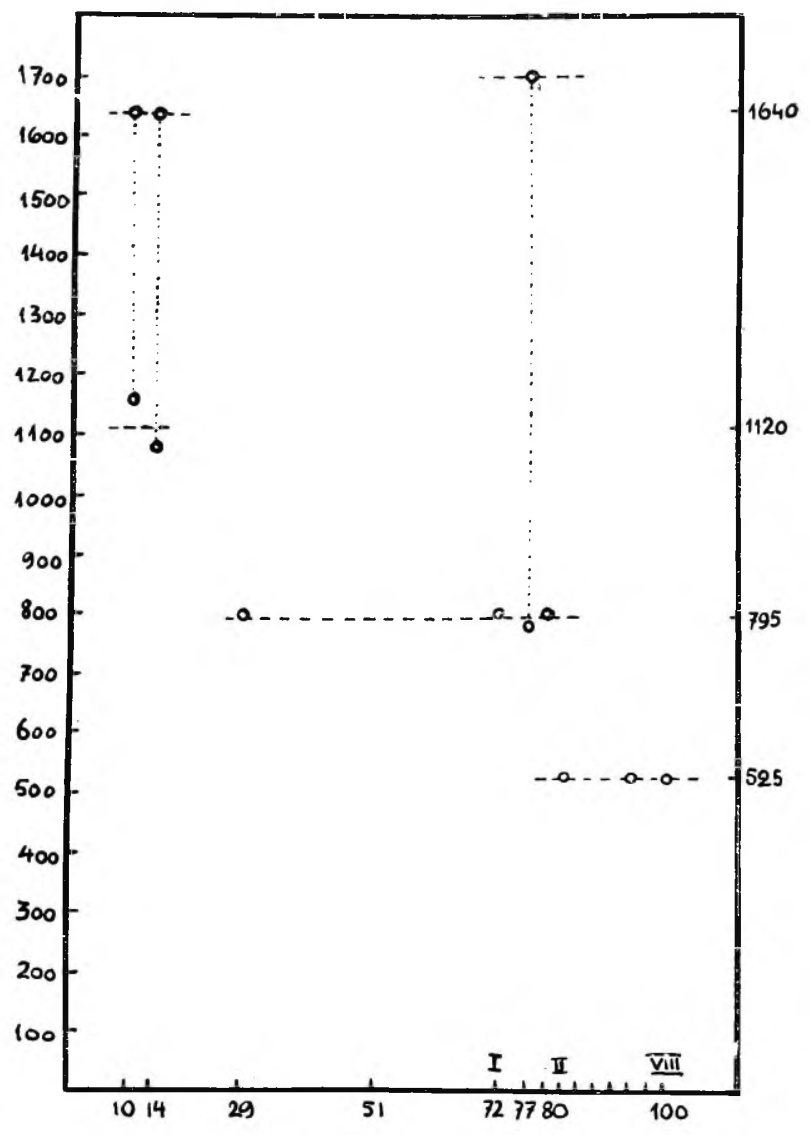

Fig. 4

Diagrama dos valores modais dos volumes nucleares do Pâncreas em cada estadio do desenvolvimento.

Em ordenadas: à esquerda: escala dos valores modais. à direita valores médios das modas de cada grupo de estadios.

Em abcissas: idade dos girinos medidas em dias a partir da eclosão até o início da metamorfose, depois desta segundo os 8 estadios "padrões"

Nos casos em que ha curvas bimodais $\left(100^{\circ}, 140^{\circ}\right.$ e $77 .^{\circ}$ dias) os dois valores modais correspondentes são reunidos por uma linha ponteada. 


\section{3) Volumes nucleares e morfologia epática}

Como já dissemos, desenhamos nas figs. I e 2 somente os gráficos de alguns estadios. Nos casos em que vários estadios apresentam curvas perfeitamente iguais, desenhamos somente uma delas.

Assim, por ex., emquanto as curvas entre $\circ 100^{\circ}$ e $\circ 14 .^{\circ}$ dia são diferentes entre si, todas aquelas compreendidas entre $\circ 29 .^{\circ}$ e $\circ 20 .^{\circ}$ dia são iguais, de modo que desenhamos somente aquelas do $72 .^{\circ}$ dia. $O$ mesmo foi feito no caso dos II, III, V e VIII estadios.

Juntamente com a descrição da curva, descreveremos também alguns aspetos da estrutura morfológica, anatómica e citológica do orgão. De modo especial estudamos a distribuição dos capilares, a estrutura do citoplasma como índice do funcionamento celular e a estrutura do núcleo (para esses fatos nós nos referimos sobretudo aos conhecidos resultados de Geitler recentemente continuados por D'Ancona nos Mamíferos). Além disso tomamos em consideração a presença ou ausência de mitoses.

\section{Girinos de 10 dias:}

- fígado ainda apresenta caracteres embrionários com cordões celulares compatos e entrelaçados com capilares não muito dilatados. O citoplasma está ainda chéio de grãos vitelinos. Mitoses bastante numerosas. Faltam células binucleadas. O núcleo aparece em repouso na maioría das células, claro, com nucleolo bem visivel, a cromatina mostra-se em granulações pequenas esparsas; alguns nucleos são mais alongados.

A curva apresenta uma ampla variabilidade e um único ápice. Foi obtida na base de 200 núcleos, sendo os resultados divididos por dois para torna-los correspondentes aos das demais curvas resultantes na base de 100 núcleos. A frequência máxima está na classe 1767; na curva calculada teoricamente a moda está no intervalo compreendido entre as classes 1276 e 1949, e graficamente foi estimada no valor de 1590.

\section{Girino de 14 dias:}

O fígado é muito mais vascularizado do que no estadio anterior, com formações de grandes séios capilares entre os cordões parenquimatosos. As células ainda contêm no plasma algumas placas vitelinas sendo, além disso, o plasma levemente vacuolizado. Os contornos celulares parecem mais nítidos do que no estadio anteriori poucas mitoses. Os núcleos são regulares. mais coráveis, com nucleolo menos evidente. As massas de cromatina são mais visíveis e maiores.

A curva de frequência possue quasi a mesma amplitude que a precedente, mas com menor regularidade. A existência de dois ápices é confirmada pela teórica que apresenta um máximo modal no valor 1150 e uma flexão no valor 1600 que faz crer na tendência para um segundo máximo naquele valor.

\section{Girino de 29 dias:}

O orgão apresenta pela primeira vez células pigmentadas e seu aspeto é muito diferente do girino de 14 dias: é mais compacto e muito menos vascularizado. As 
células apresentam contornos confusos e são menos coráveis, faltam completamente plaquetas vitelinas. Faltam mitoses. Os núcleos em sua maioria apresentam um nucleolo evidente e massas de cromatina também evidentes mas menores do que no estadio anterior, ha porém, também núcleos com o mesmo aspeto do que no estadio anterior.

A curva de frequência apresenta uma variabilidade muito mais estreita do que a anterior e nitidamente unimodal e regular, a curva teórica da um valor modal no 810 .

\section{Girino de 51 dias:}

O aspeto geral do fígado é como o anterior, apesar de serem as células pigmentadas muito mais numerosas. As células continuam com contornos pouco nítidos, ao passo que o plasma se torna cada vez mais vacuolizado. Faltam mitoses. Ha dois tipos de núcleos: os claros com nucleolo visivel e massas de cromatina muito pequenas, e os escuros som nucleolo pouco visivel e massas de cromatina maiores.

A curva de frequência é regular e com um único máximo. O valor modal é 790 .

Girino de 72 dias (início da metamorfose):

Fígado bem vascularizado, mas menos do que no estadio anterior: é pouco pigmentado. Os contornos celulares são muito nítidos e irregulare:, o plasma é claro e homogéneo. As mitoses são raríssimas. Alguns núcleos são claros com volume muito maior, sutros são mais escuros com um ou 2 nucleolos bem visíveis la estrutura é de núcleo em repouso), as massas de cromatina são granulares e pequeníssimas.

Curva de frequência regular com um único máximo. Moda 810.

Girino de 77 dias (início da metamorfose):

Aspeto do fígado como no estadio anterior, somente mais pigmentado. As células são como as anteriores, vacuolizadas. Faltam as mitoses. Núcleos como os precedentes.

Curva de frequência regular com um único máximo. Moda 810.

Girino de 80 dias (metamorfose iniciada, primeiro estadio: membros posteriores no início de seu desenvolvimentol:

O orgão é ricamente vascularizado. O plasma celular é claro e muito vacuolizado dando à célula aspeto esponjoso (o que indica presença de glicogénio dissolvido durante a preparaçãof. Mitoses muito numerosas em todas as fases. Às vezes os núcleos apresentam contornos irregulares, em alguns vê-se nitidamente o nucleolo, a cromatina acha-se em massas granulares pequenas pouco visíveis, outros são mais coráveis com nucleolo invisivel e massas cromatínicas maiores.

A curva de frequência é regular e uniapical. Moda 820 .

Girino em metamorfose: II estadio (membros posteriores bem desenvolvidos, côxas mais unidas e desaparecimento do tubo anal da lámina caudal).

O aspeto geral do fígado é como no estadio anterior, o mesmo seja dito para o plasma. Faltam mitoses. Os núcleos são menores, alguns mais claros apresentam nucleolo ao passo que outros apresentam massas cromatínicas mais grossas. 
Curva de frequência regular e mais estreita que as anteriores, com um único ápice. Moda 540 .

Girino em metamorfose: III estadio (saida do primeiro membro anterior):

O fígado é fortemente vascularizado. Contorno celular nítido, plasma cla-o e esponjoso. Faltam mitoses. Ha dois tipos de núcleos: alguns são claros, outros são escuros e irregulares. As massas cromatínicas apresentam-se sob forma de granulações nítidas e isoladas; falta o nucleolo.

A curva de frequência é regular, com um único ápice, a moda é 560, com tendência a se extender do lado dos valores mais altos.

Girino em metamorfose: V estadio (narinas rostrã's; a cauda ainda está completa):

O fígado é fortemente vascularizado. O plasma é mais esponjoso em algumas células do que n'outras. Faltam mitoses. Alguns núcleos são claros ao passo que outros são escurosi nem sempre o nucleolo é visivel. As massas de cromatina são granulares e bem visiveis, às vezes apresentam-se filamentosas.

A curva de frequência é semelhante à anterior, ha um máximo muito agudo com leve asimetria em direção das classes mais elevadas. Moda 540.

Girino em metamorfose: VI estadio (redução da extremidade caudal):

Os vasos do fígado são extremamente dilatados. O plasma é esponjoso. Faltam mitoses. Tanto os núcleos claros ccmo os escuros apresentam um nucleolo visivel. As massas de cromatina são bastante visíveis e granulares.

A curva de frequência é regular, estreita, com um ún co ápice. Moda 560.

Girino em metamorfose: VII estadio (Ccmpleto desaparecimento da lámina caudal da qual permanece apenas um pequeno cóto cônico):

○ orgão é ainda muito vascularizado. Os contornos celulares são pouco nítidos, ○ plasma é claro e esponjoso. Faltam as mitoses. Os núcleos pertencem a três tipos diferentes quanto à colorabilidade: alguns são muito escuros com conteudo muito pouco visivel, outros são mais claros e apresentam granulações de cromatina esferoidais e muito nítidas, faltando o nucleo; por fim outros (muito menos numerosos) apresentam-se com suco nuclear claríssimo e massas cromatínicas como no estadio anterior.

A curva de frequência é regular e estreitíssima. A moda está no 420 lé a curva mais estreita de todas e com valor modal mais baixol.

Girino no fim da metamorfose: VIII estadio (completo desaparecimento da cauda):

(Ha dois exemplares perfeitamente concordantes em todos os pormenores).

O fígado é notavelmente diferente de todos os estadios anteriores, mais compato, devido à vascularização menos acentuada. O plasma é menos esponjoso e mais coravel; os contornos celulares são pouco nítidos e as células pigmentadas são muito mais numerosas. Aqui também faltam mitoses. Os contornos nucleares são muito irregulares. Alguns são levemente maiores, sendo sua estrutura a de núcleos em repouso com nucleolo bem visivel. As massas de cromatina são menores, ao passo que ha outros núcleos mais irregulares e mais coráveis, com massas de cromatina visíveis. 
A curva de variabilidade é muito estreita e regular, com um unico ápice. Moda 520 (o segundo exemplar do mesmo estadio tem a moda no valor 530).

\section{4) Volumes nucleares e morfologia pancreática}

Nas figs. 2 e 4 apresentamos os dados que se referem às medidas tomadas no pâncreas. Nesse caso tambêm foram relatados somente alguns gráficos correspondentes a um exemplo de cada categoria.

Pela tabela II e III pode-se facilmente verificar que os demais estadios correspondentes comportam-se de moldo análogo.

\section{Girino de 10 dias:}

O pâncreas não se mostra muito vascularizado. Células de contornos pouco nítidos, plasma não vacuolisado e ainda rico em granulações de vitelo. Ha numerosas mitoses. Os núcleos apesar de serem de tamanho diferente apresentam-se morfologicamente iguais entre si, claros, com nucleolo grande bem visivel e massas de cromatina pequena, granulares.

A curva de frequência é muito ampla e não muito regular. Calculada teoricamente indica um valor modal entre 1600 e 1680 , e um segundo valor modal no ponto 1160 . Além disso tem a tendência à formação de uma terceira moda no valor 800 e ı ma quarta entre 2000 e 25000. (2260 V2.4).

\section{Girino de 14 dias:}

O orgão se apresenta mais vascularizado do que no estadio anterior. O plasma ainda contém plaquetas vitelinas. Ha numerosas mitoses. Núcleos tais como no estadio anterior.

A curva de variabilidade é perfeitamente regular, como dois máximos. A curva teórica possue duas modas, uma no valor 1080 e a outra, menos nítida no 1640 la curva de variabilidade representada na figura foi conseguida medindo 150 núcleos e os valores assim conseguidos foram reduzidos de $1 / 3$ para desenhar uma curva correspor. dente às outras que foram obtidas a partir de 100 núcleos).

\section{Girino de 29 dias:}

O aspeto morfológico do orgão é pouco diferente do anterior: faltam completamente os gránulos de vitelo. Mitoses ausentes. Os núcleos são levemente diferentes do que no estadio anterior. sem nucleolos e as massas cromatínicas são mais grossas e granulares. As ilhotas de Langherans são envolvidas por pigmento e bem visíveis.

A curva é mais estreita e regular. A moda está entre 790 e 800 e ha uma tendência a formar-se uma segunda perto do valor 1200 .

\section{Girino de 72 dias:}

Os contornos celulares são nítidos, o vołume plasmático é muito maior em relação aos estadios anteriores, com estrutura granular muito fina. Faltam mitoses. Núcleos 
claros com nucleolo muito grande e bem visivel, as massas de cromatina são muito pequenas. Ha numerosas ithotas de Langherans.

A curva de variabilidade é muito alongada em direção dos valores mais altos apresentando pequenas frequências. A curva teórica apresenta uma moda distinta no valor 800 e uma tendência à formação de outra perto dos 1200.

\section{Girino de 77 dias:}

O aspeto do pâncreas é como no estadio anterior. Aparecem mitocôndrios no plasma. Ha numerosas mitoses. Os núcleos e os núcleolos são bem nítidos. Massas de cromatina maiores do que no estadio anterior.

A curva de frequência é muito alargada e com dois máximos bem marcados, ha uma nítida tendência bimodal: estando uma moda no valor 780 e a outra no 1700 , ha além disso a tendência à formação de uma terceira no 1150 .

\section{Girino de 80 dias:}

As células pancreáticas contém mitocôndrios bem visíveis. Ha mitoses. Núcleos como no estadio anterior.

A curva de variabilidade é uniapical. A curva teórica apresenta uma moda no 800 e tendência à formação de uma segunda no 1150 .

\section{Girino em metamorfose: II estadio:}

O aspeto do orgão é como no estadio anterior. Os núcleos estão evidentemente em repouso e apresentam massas granulares pequenas de cromatina.

A curva de frequência é muito mais alta e estreita do que as anteriores. Aquela calculada teoricamente é unimodal com moda no 525 e tendênc'a à formação de uma segunda ao redor dos 1150 .

Girino em metamorfose: IV estadio:

- pâncreas apresenta células em contorno nítido, o plasma é escuro. Ha algumas mitoses. Os núcleos contém um nucleolo pouco visivel e massas de cromatina mais visíveis.

A curva é uniapical: a moda é 525 com uma leve irregularidade nos valores mais altos (1446) mas os dados que possuimos são demasiado escassos para toma-la em consideração.

Girino no fim da metamorfose: VIII estadio:

Pâncreas muito pouco vascularizado. Faltam as mitoses. Os núcleos têm um nucleolo muito pouco visivel e massas de cromatina grandes e granulares. Ha numerosas ilhotas de Langherans.

A curva de variabilidade é muito regular e estreita, uniapical com moda no 523. 


\section{5) Discussão cíos resultados}

\section{a) Diminuição rítmica e problema das sub-classes intermediárias}

Pela observação dos diagramas Fig. 3 e Fig. 4 e da tabela III, nota-se que, durante o desenvolvimento do girino, o volume nuclear, quer do fígado, quer do pâncreas, diminue progressivamente.

Essa diminuição é descontínua e se observarmos os valores numéricos, veremos que podem ser dispostos numa série que se aproxima notavelmente daquela analizada por Brummelkamp numa trintena de casos de variações. volumétricas nucleares.

O fato fundamental que transparece dessas observações é o volume nuclear sofrer duas successivas reduções pela metade idurante o desenvolvimento e a metamorfose do girino.

O valor inicial dos núcleos do esboço epático apenas diferenciado do endoderma vitelino $\left(100^{\circ}\right.$ dia). fica reduzido pela metade durante todo o. período pre-metamórfico (do vigésimo nono ao octuagésimo dia), e novamente se biparte no fim ida metamorfose (no VII estadio).

Essas duas successivas diminuições são obtidas passando por dois estadios intermediários (14. ${ }^{\circ}$ dia e do II ao VI estadio), sempre porém, de modo descontínuo.

Apesar das relações entre os valores dos estadios intermediários com os que podemos chamar de fundamentais (porque constituem a série de bipartição) parecerem constantes (tb. IV) e coincidentes com aqueles indicados por Brummelkamp (módulos 1:41 $=\sqrt{ } 2$ ) não nós parece ainda ser possivel afirmar, baseando-nos nos dados dessas pesquizas, que os valores intermediários possam ser considerados como termos efetivos de uma série geométrica que compreenda todos os valores.

Por ora nós constatamos esses fatos e parece-nos que, prescindindo por um momento dos valores intermediários, no nosso caso é evidente estar em jợgo uma série geométrica com módulo igua! a 1/2, definida pelos volumes através dos quais passa o núcleo nos 3 momentos fundamentais da vida larvária, isto é: diferenciação do esboço epático (volume compreendido entre 1590 e 1600), premetamorfose (810-800) e final da metamorfose (420-400).

Parece-nos, portanto, que esses fenômenos caem na órbita da "Protomerentheorie" de Heidenhain e indicam uma relação constante de duplicação, ou antes, nesse caso, de bipartição das variações quantitativas da substância viva.

Mais acima dissemos que não julgamos ser possivel, sem mais nadá, considerar os valores intermediários da série reducional como fazendo parte 
de uma série geométrica com módulo 1,4!. Essa nossa opinião é baseada sobretudo no fato da interpretação de Brummelkamp da "série $\sqrt{2 "}$ não nós parecer a única possivel. Outras explicações, baseadas noutros fatos, podem ser utilizadas para explicar o fenômeno das classes intermediárias: pesquizas em andamento permitir-nos-hão escolher, no futuro, uma dentre essas outras possíveis explicações.

Mencionamos na pag. 214 a interpretação de $G$. Hertwig sobre os estadios intermeidiários: mas esta tão pouco nos satisfaz, sobretudo devido à escolha que este $A$. fez dos fatos que serviram como ponto de apôio.

Deixamos, portanto, suspensa, por emquanto, a discussão deste capítulo e nos limitamos a verificar fatos, esperando que as pesquizas em andamento sobre outro material nos dêm a base para uma interpretação melhor.

Quanto às observações morfológicas, pudemos observar algumas diferenças nos núcleos dos estadios com valor intermediário $\left(14 .^{\circ}\right.$ dia e estadios da metamorfose). Como já frizamos na descrição particular de cada caso, naqueles com valor intermediário o núcleo apresenta uma estrutura diferente daquela que geralmente se denomina núcleo em repouso" A cromatina se mostra em grupos mais visíveis e falta completamente o nucleolo. Ha tambêm estruturas intermediárias entre essa e a dos núcleos em repouso, mas certamente não nos parece despido de interesse este fato que constitue uma certa analogia com as estruturas que D'Ancona verificou no fígado dos Mamíferos durante a "endósquise" e que pode relacionar-se às considerações de Bogoiawlewski sobre as relações entre o volume nuclear e sua estrutura no Anopheles (1935).

Para terminar estas observações faremos ainda notar que na definição das "classes" e "sub-classes" dos valores nucleares, têm importância fundamental tanto a determinação do valor máximo inicia! no momento da diferenciação do orgão primordial, como o valor mínimo alcançardo no decorrer da ontogénese, no momento do início de sua atividade específica. No caso por nós estudado da série epática, a série de valores inicia-se, com notavel aproximação, com um valor 8 vezes maior do que o mínimo, e não nós parece completamente despido de interesse a consideração que as sub-classes" udesse modo estabelecidas, apresentam de preferência os núcleos naquele estadio de "movimento interno" ao qual nós nos referimos ha pouco, emquanto que nos estadios correspondentes às "classes" múltiplas de 2, os núcleos se acham em sua grande maioria em repouso.

Visto que constatamos esta diminuição e demonstramos que ela se dá por saltos successivos, parece-nos interessante analisar o fenômeno sob outro ponto de vista. 
Surge a dúvida se esta redução se dá progressivamente durante o desenvolvimento do girino e os núcleos de um estadio se reduzem de fato ao valor que nós achamos estatisticamente dominante no estadio successivo, ou se esta redução rítmica não é antes um resultado aparente, de ordem estatística, devido ao aumento em tempos successivos de núcleos de tamanhos diferentes já existente desde os primeiros momentos da formação do esboço embrionário.

Para esclarecer este ponto é necessário verificar se realmente o tecido epático apenas diferenciado da larva joven, já contém todas as classes volumétricas que se acham mais tarde nos estadios successivos como classes de maior frequência.

A observação morfológica do esboço epático, mostra indiscutivelmente, que os núcleos das células viíelinas, ainda deformados pela presença de gránulos de reserva tornam-se diretamente os núcleos epáticos da classe máxima verificada na nossa série. Comparamos as observações feitas em Bufo, tambêm sobre uma série de girinos de Rana catesbiana, que compreende estadios precedentes aos primeiros da série de Bufo que possuimos.

Não ha dúvida alguma que o valor primordial epático é aquele da classe modal do 10.' dia, mas com isso não se exclue que dessas células primordiais desde o início, por redução rítmica, se formem células que pertencem às classes inferiores, que constituem reservas à custa das quais por sucessivas ondas de reprodução (e conseguinte ideslocamento dos valores modais) o fígado cresce nos vários períodos.

O estudo biométrico que levamos a efeito mostra uma dispersão muito grande (veja par. b), cap. 5) no polígono de frequência do $100^{\circ}$ dia. Isso indica a existência, já naquela época, de classes volumétricas imediatamente inferiores à máxima. Faltam completamente, pelo contrário, as classes menores que aparecem somente nos diagramas dos estadios mais adiantados.

Estes fatos em si já apresentam uma resposta parcial ao problema que nos apresentamos. Ao menos alguns dos estadios da redução se dão em épocas posteriores à formação do esboço epático.

O efeito "estatístico" por assim dizer, do deslocamento da moda para valores mais baixos pode ser causado tanto pela reprodução de células de reserva menores, como pela redução de núcleos maiores, sendo porém que isso não esclue possa haver redução.

Trata-se agora de decidir se todas as células se reduzem mais ou menos sincronicamente em épocas sucessivas, ou se pelo menos um determinado número constitue uma reserva já reduzida, proveniente de estadios anteriores e que entra em proliferação (mitótica ou amitótica) no momento em que é possivel verificar um deslocamento modal. 
Isso é porém um problema secundário, que tem por objeto o momento. no qual se dá a redução e que não interfere com o que mais nos interessa: a redução em si.

Se nós fizermos a comparação entre a redução rítmica do volume nuclear que estudamos nesses casos e o crescimento que, no mesmo tipo de células. em outros casos foi estudado recentemente, somos imediatamente levados a. crêr que existe uma correspondência não somente dos fenômenos, mas tambêm dos mecanismos que os produzem.

Admite-se, geralmente, que a duplicação do volume nuclear se obtém com a duplicação do que Heidenhain chamou "protomeren" (o que parece nada mais ser do que o genoma), sem que haja uma correspondente scisão do núcleo em dois núcleos filhos. Esta duplicação pode ser alcançada por meio de uma duplicação quer no número (duploidismo: Frolowa, Geitler) quer no volume dos cromosomas bivalentes ou bímeros: $G$. Hertwig).

Mas, pelo contrário, não é facil acreditar numa redução rítmica do volume nuclear sem uma correspondente divisão; até hoje, pelo menos, não. conhecemos nenhum fato que nos permita crêr numa espécie de "contração, rítmica do volume nuclear. Os casos conhecidos de redução rítmica nuclear recaem todos no quadro das divisões meióticas com repartição entre os. dois filhos do patrimônio gênico do núcleo originário e sabemos que tal divisão pode dar-se várias vezes em seguida quardo o núcleo originário é polímero ou poliploide do genoma (Multiplesuccedantheilungen de $G$. Hertwig).

Devido a estes fatos somos levados a perisar que tambêm no caso dos. núcleos do fígado e do pâncreas aqui estudados, i. é, ule núcleos somáticos" a diminuição rítmica é devida a sucessivas divisões sem correspondente duplicação do genoma antes de cada uma dessas divisões.

$\mathrm{Na}$ série de girinos por nós examinada, vimos que as células epáticas. estão em mitose somente nos estadios imediatamente anteriores a uma redução de volume, um fato análogo foi encontrado por B. Schreiber e Angeletti na diminuição rítmica do volume nuclear da Carpa. Imediatamente nós. nos perguntamos se tal fato poderia de certo modo ser tomado como gúia. na interpretação do mecanismo da diminuição

\section{b) Problemas inerentes às mitoses e à amplitude da variabilidade nuclear}

Afirma-se, em geral, que as células epáticas dos Vertebrados superiores não se reproduzem por mitoses depois de findo o período embrionário, mas. os numerosos autores que trataram desse assunto não estão de acordo em tal afirmação. Emquanto muitos descreveram mitoses epáticas, Max Clara e seus alunos acharam serem elas extremamente raras. Este autor estudou o. 
problema da discordância tão evidente entre as observações dos vários autores e a possibilidade disso ser devido a condições diferentes das células nos vários casos estudados.

Uma causa dessa discordância parece-nos possa tambêm ser encontrada no fato, por nós verificado, de na série do desenvolvimento do Bufo acharmos mitoses relativamente frequentes em alguns estadios e ausentes em outros.

A multiplicação das células epáticas é, portanto, descontínua. O que mais interessa no nosso caso é que os periodos de multiplicação mitótica se acham em correspondência com os periodos de redução do volume, alternando-se com aqueles em que falta qualquer multiplicação e nos quais os núcleos se apresentam em repouso. Achamos mitoses nos estadios do $10 .^{\circ}$ e do $14 .^{\circ}$ dia, e no fim do longo periodo pre-metamórfico entre $072 .^{\circ}$ e $\circ$ $80 .^{\circ}$ dia, emquanto faltam durante a premetamorfose e durante as fases da metamorfose.

Qual é o significado que devemos atribuir a estas mitoses? São elas mitoses normais que conduzem à multiplicação de całegorias de células existentes, ou são antes mitoses reducionais que dão origem a classes inferiores, mais ou menos analogamente ao que se dá na gametogénese?

Procuramos ver, no material usado nas pesquizas anteriores, se coisa similar a tudo isso se dá no fígado e no pâncreas.

Desde já devemos dizer que não nos foi possivel efetuar uma contagem cromosómica, e que somente pudemos estabelecer, baseando-nos numa pesquiza estatística dos volumes dos núcleos em divisão, que estas células pertencem a várias classes de frequência, e que a variabilidade é notavelmente ampla. Não nos pareceu pois oportuno tomar um valor modal que, dado o número relativamente pequeno de casos, não teria valor.

Não pudemos observar nenhum outro fato que indicasse uma alteração nos cromosomas, quer no número quer no volume. Evidentemente estes fatos não são suficientes para esclarecer o problema; estão atualmente sendo feitas pesquizas sobre outro material sobre o mesmo assunto.

Do ponto de vista estatístico, a asimetria para a direita das curvas de variabilidade, indica que as mitoses se dão nas células das classes maiores, $e$ isto nos parece interessante para a interpretação do fenômeno reducional como o apresentamos mais acima; i. é, que não se trate de multiplicações de células pequenas já presentes no tecido.

Devemos ainda frisar que, por mais cuidadosas as observações feitas, nào nos foi possivel encontrar células binucleadas, nem núcleos em divisão clireta nas células epáticas.

Dado o estado da questão, nós nos limitamos por ora a admitir, por pura analogia com a série de crescimento rítmico dos volumes nucleares, que 
no nosso caso se verifica uma diminuição do genoma (polímero ou poliploide) das células epáticas e pancreáticas primordiais, sem discutirmos o mecanismo desta redução.

Um problema que muito preocupou aiguns dos autores que se dedicaram a pesquizas desse, tipo foi o do volume mínimo (Minimale mögliche Klasse: Wermel), volume esse do qual partiriam as células de um orgão ou tecido no seu crescimento rítmico durante o desenvolvimento. No caso aqui estudado, este problema se apresenta mais complexo. De fato devemos considerar antes de tudo um "volume máximo primordial" do qual as céiulas oartem no seu processo de diminuição rítmica. Alcançado depois o volume mínimo, elas poderão eventualmente aumentar de novo. Efetivamente isto se dá na Carpa, no nosso caso, pelo contrário, tal não é evidente, pois faliam os estadios postmetamórficos. Na realidade vimos que quando esta está a findar é alcançado um volume mínimo /que escolhemos como unitário na série geométrica por nós adotadal e que, depois de completa a metamorfose, volta o volume a um valor modal pertencente à classe imediatamente superior à mínima. Por analogia com o caso da Carpa poidemos pensar que, com efeito, isto se dê, mas julgamos necessária uma verificação mais rigorosa no caso ds Anfíbios. Wermel e lgnatiewa verificaram na Rã curvas com três ápices nos volumes nucleares epáticos.

B. Schreiber e Angeletti demonstraram que o volume mínimo coincide com o início do funcionamento específico da célula epática. Evidentemente esse volume mínimo deve ser uma característica do tecido e deve estar relacionado ao mecanismo da diferenciação citológica e histológica. Nos tecidos em que se dão estes fenômenos, o significaldo da classificą̧ão de Levi e Bizzozzero é de certo modo modificado, e uma revisão dos vários tecidos sob este ponto de vista seria vatiosa.

Tal classificação é pelo menos válida a partir dos valores mínimos. Igualmente importante se nos apresenta o valor do volume epático originário, que marca o momento em que, na embriogénese, se forma o tecido em questão. Mas o que acontece no intervalo entre o volume máximo originário e o mínimo? Evidentemente o orgão aumenta de volume e diferencia-se. Nesse caso está o mecanismo da diminuição intimamente ligado a estes fenômenos? Parece-nos que estas considerações podem constituir um ponto de saida para um novo campo de estudos sobre o desenvolvimentc embrionário e post-embrionário.

Um fato que imediatamente chama a atenção ao observarmos os poíigonos de trequëncia dos vários estadios, é a notavel diferença da amplitude total da variabilidarde. Estas observações referem-se especialmente ao fíga- 
TABELA $V$

\section{AMPLITUDE DA VARIABILIDADE (DISPERSÃO) NO FÍGADO DURANTE O DESENVOLVIMENTO}

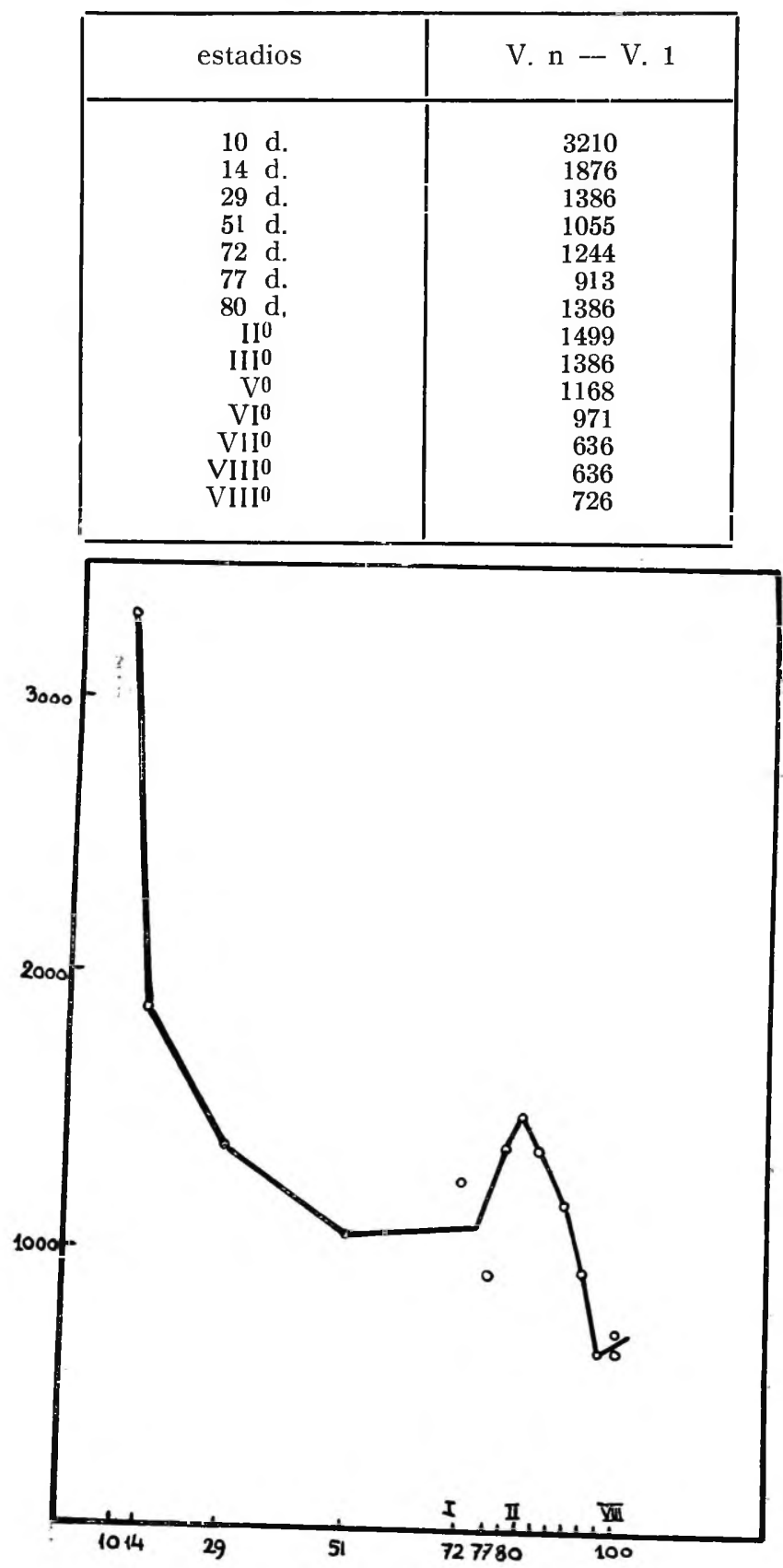

Fig. 5

Variação da amplitude da variabilidade nuclear epática durante o desenvolvimento. Os dados do $72 .^{\circ}$ e $770^{\circ}$ dias são discordantes, e a curva foi construida sobre o valor médio entre os dois. (Veja a nota na pag. 256). 
do no qual ocorrem todos os fenômenos aqui analizados e que são muito mais nítidos e exatos que no pâncreas.

Como "amplitude da variabilidade" consideramos a diferença entre os valores da classe máxima e da minima dentro de cujos limites varia o volume nuclear de um determinado estadio.

Pareceu-nos interessante perquirir melhor este fato e com este fim construimos o diagrama da fig. 5 marcando em abcissas os estadios do desenvolvimento e em ordenadas os valores da amplitude da variabilidade (dispersão). A curva assim obtida mostra um valor inicial máximo $110100^{\circ}$ dia, e este diminue rapidamente até cerca meiados do periodo premetamórfico $150{ }^{\circ}$ dia). Depois disso a variabilidade aumenta de novo e alcança um segundo máximo nos primeiros estadios da metamorfose, para depois cair rapidamente num mínimo no VII. ${ }^{\circ}$ estadio.

Vemos, portanto, que a amplitude da variabilidade do volume nuclear tende nitidamente a diminuir depois da eclosão até alcançar a metamorfose, e além disso vemos que esta diminuição é interrompida por um periodo de maior variabilidade no início da metamorfose.

E' evidente que esta variabilidable está em relação com os fenômenos morfogenéticos que se sucerdem nestes periodos, além de estar em relação com a presença de mitoses, como já frizamos no parágrafo anterior.

A existência, por via de regra, de uma atividade poliferadora num tecido, manifesta-se estatisticamente por uma asimetria do lado direito (valores mais altos) do poligono de frequência (Wermel), e este fato é muito nítido na nossa série e de modo especial nos estadios precoses da metamorfose. No fim idesta é alcançado o valor mínimo de variabilidade. Devemos, portanto, deduzir que a atividade proliferadora se extinguiu completamente e que o tecido se acha num periodo de completo repouso.

(*) Na tabela $V$ e na Fig. 5, nota-se uma discordância entre os valores da amplitude da variabilidade entre $\circ 72$ e $\circ 77$ dia. A curva foi construida para o valor intermediário destes dois.

Julgamos exato fazer esta aproximação baseando-nos nas verificações feitas por um de nós num trabalho anterior executado sobre a mesma série de girinos $(G$. Schreiber e C. Koch, 1941). Neste trabalho foi constatado que o exemplar de 72 dias apesar de ser mais joven, está mais adiantado na metamorfose do que o de 77 dias. Uma discordância perfeitamente semelhante a esta foi naquela ocasião posta em relevo também para outras manifestações quantitativas da metamorfose entre estes dois exemplares (desenvolvimento da camada ganglionar da retina).

A variabilidade individual, relativamente pequena no perioda pre-metamórfico, acentua-se notavelmente no periodo da metamorfose e este fato nos induziu a abandonar a determinação do estadio baseando-nos na idade depois de iniciada a metamorfose e a -adotar uma classificação em estadios "padrões" para este periodo (G. Schreiber. 1937). 
Quanto às relações de correspondência entre estes periodos de maior variabilidade celular e os de diminuição volumétrica, podemos idizer que a maior variabilidade dos volumes coincide com os periodos em que se dá a redução. É este um efeito estatístico facilmente compreensivel devido à coexistência de um maior número de classes.

Max Clara (1931), considerou a variação ida amplitude da variabilidade durante os vários periodos do desenvolvimento, em sentido contrário àquele por nós agora tomado em consideração, mas se examinarmos o fato objetivamente veremos que de modo algum ha discordância entre esses dois casos. No fígado dos Mamíferos, Clara verificou curvas muito mais "estreitas" durante o periodo embrionário e muito mais largas no adulto. Mas isto é devido ao fato de, nos embriões de Mamíferos, se acharem células que pertencem a uma só classe, ao passo que à medida que o animal envelhece aparecem nele os fenômenos da endósquise e núcleos das classes superiores assim como também células binucleadas. A coexistência de várias classes celulares determina naturalmente uma maior amplitude do polígono de frequência, como no nosso caso em que aparecem também classes inferiores. Quando não entram em jogo fenômenos de diminuição (periodo premetamórfico e fim da metamorfose), as curvas de frequência são estreitíssimás.

\section{c) Diferenciação citológica e crescimento geral do fígado.}

E' sabido que nos Mamíferos o fenômeno da endósquisə, ou multiplicação interna dos núcleos epáticos, tem tambêm como consequência o aumento volumétrico do próprio fígado. E' portanto uma das causas do crescimento do orgão. (M. Clara).

No caso da diminuição rítmica dos volumes, o problema da participação das células no aumento volumétrico do orgão, apresenta-se mais complexo. Nós não consideramos este problema de modo especial, mas nos parece interessante por estar relacionado à diminuição rítmica, porque ele se liga tambêm ao processo de diferenciação funcional das células, fenômeno que iá mencionamos mais acima.

Não sabemos se os períodos nos quais ha mitose e nos quais verificamos a manifestação dos fenômenos de diminuição nuclear, correspondem ou não a outros tantos períodos de maior crescimento geral do fígado.

Pela simples observação dos cortes, resulta haver um notavel aumento do fígado no período inicial da metamorfose, mas não podemos apresentar aqui nem dados numéricos relativos a este fato nem ao ritmo deste aumento. $\mathrm{Na}$ análise de cada caso relatamos as observações sobre o estado de vascularização do orgão e sobre a estrutura do plasma das células epáticas, tendo justamente em vista uma possivel interpretação dos fatores que in- 
fluem sobre o aumento volumétrico do fígado, independentemente da atividarde reprodutora de seu parênquima.

Como foi posto em evidência por um de nós numa pesquiza sobre a curva de crescimento da tiroide embrionária (Schreiber e Gambaro), pode-se decompor a curva de crescimento de um orgão num determinado número de "fases" sendo cada uma caracterizada por um fator prevalente que contribue para o aumento volumétrico. Estes vários fatores que se seguem durante a ontogénese, poldem ser completamente independentes e diferentes, como por ex. a atividade proliferadora do parênquima, a diferenciação funcional do citoplasma e a vascularização.

Os mesmos fenômenos verificam-se certamente tambêm no desenvolvimento do fígado dos girinos influenciando independentemente o tamanho do orgão e interferindo o seu crescimento total. De modo especial interessa-nos aqui, além do fator proliferação (que vimos ser complicaslo pelos fenômenos de diminuição) tambêm o fator de diferenciação do citoplasma epático.

Já mencionamos mais acima que esta diferenciação parece coincidir com a fase do tamanho mínimo alcançado pelo núcleo. Chama a atenção - fato de, no fim da metamorfose, verem-se células epáticas muito maiores que nos estadios anteriores, mas com núcleo muito menor. Imediatamente pensa-se na relação núcleo-plasmática como foi estudada com muito interesse por vários autores. Não efetuámos nenhuma medida neste campo, porque achámos completamente errôneo considerar o volume celular como representando de fato o verdadeiro volume protoplasmático, especialmente nas últimas fases da metamorfose. E' de fato sabido que, nos Anfíbios, as células epáticas principiam sua função glicogenética justamente por ocasião da metamorfose (Aron) e nestes estadios as células se apresentam fortemente vacuolizadas: acumulação de glicogénio que desaparece durante a preparação, conferindo ao protoplasma aspeto esponjoso. O mesmo fato foi observado por B. Schreiber e Angeletti no desenvolvimento das Carpas, que, como já várias vezes frizamos, coincide com o fim do período de diminuição do volume nuclear, e para os Mamíferos (Müller) a aquisição da estrutura histológica definitiva do orgão coincide com o aparecimento de curvas bimodais para os valores volumétricos.

Por ocasião da metamorfose a vascularização é bastante acentuada e amplos seios vasais percorrem o parênquima epático e contribuem notavelmente para o crescimento geral do orgão. Este aumento da circulação epática está certamente em relação com o aumento de funcionalidade das células, o que vimos manifestar-se tambêm pela sua morfologia.

Todos estes pontos interessam ao problema específico de nossa pesquiza, porquanto concorrem para demonstrar nitidamente a atividade fun- 
cional do orgão. Fica, portanto, demonstrado como positiva a coincidência do volume mínimo nuclear com a menor variabilidade do volume nuclear e com a obtenção da completa diferenciação funcional da cé.ula epática.

\section{6) Resumo e conclusões}

Estudamos os volumes nucleares do fígado e do pâncreas numa série de girinos de Anuro, compreendida entre o 10. dia depois da eclosão e o fim da metamorfose. Os estadios foram definidos pelo número de dias até o início da metamorfose e, durante esta, por meio de estadios 'padrões' (segundo a classificação de $G$. Schreiber, 1937).

Calculamos o valor modal para cada estadio do desenvolvimento da larva e estudamos a variação deste valor 'durante o período pre-metamórfico e metamórfico.

Desta pesquiza resultaram os seguintes fatos e deles tiramos as :eguintes conclissões:

1) o volume nuclear destes orgãos diminue a partir da eclosão até a metamorfose. Esta diminuição é descontínua.

2) as diminuições dos volumes se dão nos estadios $10 .^{\circ}, 14 .^{\circ}$ 80.' dias e no VI. ${ }^{\circ}-$ VII. ${ }^{\circ}$ da metamorfose. Nos $10 .^{\circ}, 14 .^{\circ} \mathrm{e} 80 .^{\circ}$ dias são numerosas as mitoses, sobretudo no fígaldo.

3) os polígonos de frequência apresentam um único máximo, para o fígado, ao passo que o pâncreas apresenta em algui-s estadios $\left(14.0^{\circ}\right.$ e $77.0^{\circ}$ dial polígonos com dois ápices.

A amplitude da variabilidade é diferente nos vários estadios e geralmente vai diminuindo desde a eclosão até a metamorfose. No início da metamorfose ha, porém, um notavel aumento da variabilidade que diminue depois, perto do fim da metamorfose.

4) observámos que o máximo volume que achamos (10. clia) correspo-do ao volume dos núcleos da célula epática apenas diferenciada do oridoderma vitelino, ao passo que o volume mínimo se acha no fim da metamorfose e corresponde à célula perfeitamente diferenciadas e blotadas de função específica. Indicando por I o menor volume meldido na nossa série, vemos que a célula epática apresenta volume 4 por ocásião de sua diferenciação do endoderma vitelino, diminue até ter volume 2 durante todo o período pre-metamorfico e alcança o volume 1 no fim da metamorfose.

Entre estes valores ha porém dois saltos intermediários (14." dia e início da metamorfose) nos quais diminue o volume nuclear, sempre de 
modo discontínuo, até alcançar um valor cerca de 1,4 menor do que o anterior.

5) discutimos o provavel mecanismo e o significado desta diminuição, relacionando-os com os fenômenos de crescimento rítmico do volume nuclear no fígado e no pâncreas dos Mamíferos e à "Protomerentheorie de Heidenhain.

6) discutimos o significado destas classes intermediárias, ainda não bem definido. De qualquer modo permanece evidente a existência de valores seriados segundo um múltiplo de 2, durante os momentos fundamentais da ontogénese, que nos autorizam a crêr, tambêm neste caso e apesar dos valores intermediários, verdadeira a hipótese da variação rítmica por bipartição, como no caso do desenvolvimento da Carpa. Como conclusões gerais das presentes pesquizas, julgamos poder afirmar que nos tecidos que estudamos e de modo particular no fígado a diferenciação citológica e funcional está relacionada com uma diminuição rítmica do volume nuclear. Esta diminuição é, com todlas as probabilidades, ligada a fenômenos dé divisões celulares, cujo mecanismo e cuja natureza não nós foi possivel indagar.

$\mathrm{Na}$ nossa série não pudemos observar, pelo menos tão claramente, o aumento rítmico do núcleo epático que se da depois de alcançado o volume mínimo e a diferenciação celular, como já foi verificado na Carpa.

De qualquer modo parece-nos que o conceito de "células estáveis" da classificação de Levi-Bizzozzero deve ser, nos casos em que intervêm fenômenos como os que analizamos, integrado pela aplicação do conceito de "volume máximo inicial" correspondente ao momento da formação do orgão embrionário e tambêm pelo conceito de "volume mínimo" correspondente ao momento definitivo da diferenciação funcional do tecido.

Esta diminuição do volume nuclear no período que precede a especialização do tecido, faz-nos lembrar e não só por mera analogia, mas talvez por correspondência de mecanismo e de significado na diminuição do volume nuclear o que é a característica das gerações sucesivas ide blastómeros no período tŕpico da segmentação.

\section{7) Summary}

RHYTMIC DECREASE OF NUCLEAR SIZE IN LIVER AND PANCREAS CELLS OF ANURA TADPOLES

The nuclear size of liver and pancreas cells was studied in a series of Bufo vulgaris tadpoles from the l0th day after hatching to the end of metamorphosis. 
1) The nuclear size (volume) of liver and pancreas cells decreases from hatching to the end of metamorphosis. This decrease is discontinuous (rhythmic).

2) Decrease of nuclear size appears at the 10th-14th-80th day, and during the last stages of metamorphosis (VI. and VII. standard stages as previously described by the author). Many mitoses appear during some of these stages.

3) Frequency curves of the nuclear volume were made and their modal value calculated. The dispersion of the curves decreases markedly during development, but the beginning of metamorphosis is characterized by a higher dispersion.

4) The largest nuclear size is observed in the 10th day tadpole, when the liver is newly differentiated from the endoderm and is still filled with yolk granula. The smallest nuclear size is found at the end of metamorphosis (stage VII), when the liver cell is morphologically and functionally well differentiated. If the size (modal value) of the smallest nucleus is indicated with I the liver nucleus has the volume 4 at the moment of its differentiation from the endoderm, volume 2 during the whole premetamorphic period and volume 1 at the end of metamorphosis.

Between these volumes there are two intermediate stages (at the I4th day and at the beginning of metamorphosis, stage (I to VI), during which the nucleus appears nearly 1,4 times smaller than the preceeding one ("intermediate classes of volumes").

5) The probable mechanism arid significance of this diminution is discussed, considered in relation to rhythmic growth of liver nuclei in Mamma!s (Jakobi) and included in the theory of protomeres (Heidenhain).

6) For understanding the significance of the "intermediate classes of nuclear. volumes" the results of new researches or: different tissues must be waited for. It is however possible in spite of these intermediate stages to verify the rhythmic decrease of liver nuclei with the ratio $1: 1 / 2$ during the fundamental stages of tadpole development; this confirms preceetding analogous statements of B. Schreiber and Angeletti in the carp.

In the studied tissues the cytological and physiological differentiation is connected with a rhythmic decrease of nuclear size; this decrease is probably reached through cell divisions.

The conception of "stable cells" of Levi-Bizzozzero's tissue classification must be modified in these cases. We must consider an "initial size" corresponding to the origin of an embryonic organ, and a "minimal size" corres- 
ponding to the moment in which the tissue reaches its cytological and physiological differentiation.

The blecrease of nuclear size during the period preceeding specific differentiation of the tissue recalls the nuclear diminution in the successive generations of blastomeres during the period of cleavage.

\section{8) Bibliografia}

ARON M. 1931 Recherches histophysiologiques sur le fonctionnement et les correlations des glandes endocrines embryonnaires chez les Vertebrés. - Bull. Biol. de la France et Belgique. T. LXV.

BOGOJAWLEWSKJ K. S. 1935. Studien ueber Zellengrösse und Zellenwachstum XI Mitt: Ueber Beziehung zwischen Struktur und Volumen der somatischen Kerne bei Larven von Anopheles maculipennis. - Z. Ze!lf. mikr. Anat., 22.

BRUMMELKAMP R. 1939, Das sprungweise Wachstum der Kernmasse. - Acta Neerlandica Morphologiae, vol. II, pag. 177.

CLARA M. 1930, Untersuchungen an Hodenzwischenzellen bei einigen Haussäugetieren. - Zt. mikr. anat. Forsch. 20.

- 1930, Untersuchungen an menschlicher Leber. II: ueber die Kerngrüssen in den Leberzellen. - Zt. mikr. anat. Forsch., 22.

- 1931. Accrescimento e rigenerazione dei tessuti ad "elementi stabili" - Monitore Zool. Italiano, L.

FISCHER I. 1936, Ueber den Wachstumsrhytmus des Follikelepitels der Läuse und Federlinge und Beziehungen zum Arbeitsrhytmus der Zelle und Amitose. - Arch. Zellf. mikr. Anat.. 23.

FREERKSEN 1933, (cit. Wermel VIII Mitt.)

FROLOWA S. 1929, Die Polyploidie siniger Gewebe bei Dipteren. - Ztschr. f. Zellf. u. mikr. Anat., 8.

GEITLER L. 1937, Die Aralyse des Kernbau und der Kernteilung des Wasserkäfers (Gerris lał. und Gerris lacustris) Hemiptera Hoteroptera) und die Soma Differenzierung. - Z. Zellf. u. mikr. Anat., 26.

- 1939. Die Entwicklung der polyploiden Somakerne der Heteroptera durch Chomosomenteilung ohne Kernteilung. - Chromosoma Ztschr. f. Zellkern. Chromosomenforsch. Bd. I.

HEIDENHAINI M. 1923. Formen und Kräfte in der lebendigen Natur. Beit. VII zur synthctischen Morphologie. Vorträge u. Aufsätze üb. Enntwicklungsmech. d. Organismen. Bd. 32.

HERTWIG G. 1932, Dos Befruchtungs und Vererbungsproblem im Lichte der vergleichenden-quantitativen Kernforschung. Anat. Anzeig. 75.

- 1931, Allg. Betrochtungen ueber Kernwochstum und Kernteilung auf Grund eines Vergleiches der Kerngrösscn von somatischen und generativen Zellen bei Maus und Ratte. - Sitzb. u. Abhandl. Naturforsch. Ges. Rostock. 3 folgl. B. 3.

- 1933, Die dritte Reifeteilurg in der Spermatogenese des Menschen und der Katze in ihrer experimentellen Auslösung durch Prolan im jugendlichen Rattenhoden. Ztsch. mikr. anat. Forsch. 33. 
HERTWIG G. 1939, Abweichungen von dem Verdoppelungswachstum der Zellkerne und Ihre Deutung. - Anat. Anzeiger Verhand. d. Anat. Geselleschaft Bd. 8701939.

- 19.39. Der Furchungsprozess des Mauseeies ein Bejspiel für die wiederholte Volumen-halbierung polymerer Kerne und Chromosomen durch multiple Succedanteilungen. - Z. f. mikr. arit. Forsch. 45.

JAKOBI W. 1925, Ueber das rhytmische Wachstum der Zellen durch Verdoppelung ihres Volumens. - Roux Arch. Bd. CVI, p. 124.

- 1926, Uber das Wachstum der Zelle nach einem Gesetz der kostanten Proportionen. - Münchn. Med. Wschr. 20850.

- 1926, Die Kerngrössen der männlichen Geschlechtszellen beim Säugetiere in Bezug auf Wachstum und Reduktion. Beitrag XI: zur synthetischen Morphol. — Ztschr. f. Anat. u. Entwicklungsgesch. Bd. 81 m. 563.

- 1931, Volumetrischen Untersuchungen an den Zellkernen des Menschen und das allgemeine Problem der Zellkerngrösse. - Verh. Anat. Ges. Anat. Anz. Erg. Heft, Bd. LXXII, p. 236.

KELLER C. 1933. Vergleichende Zellen-und Kernmessungen bei grossen und kleinen Hühnerrassen zur Prüfung der genetisch bedingten Wuchsunterschiede. Zugleich ein Beitrag zur Frage des rhytmischen Wachstums der Kerne. -- Ztschr. f. Zellf. u. mikr. Anat. Bd. 19 p. 510-536.

LEVI G. 1925, Wachstum und Körpergrösse. Die strukturelle Grundlage der Körpergrösse bei vollausgebildeten und im Wachstum begriffenen Tieren. - Ergb. der Anat. ui Entwickłgesch. Bd. 26. P. 87.

- 1935, Trattato di Istologia. II Ediz. - UTET, Torino.

MOLLER G. H. 1937, Die Entwicklung der Kerngrössen Verhältnisse in der Leber der weissen Maus. - Ztschr. f. mikr. anat. Forsch. 41.

NIERO G. 1934. Primi risultati di misurazioni nucleari sul fegato degli Anfibi. - Monit. zool. Italiano suppl. vol. XLIII p. 238.

SAUSER G. 1936, Die Grösse des Zellkernes in verschiedenen Tierklassen unter Berücksichtigung des Geschlechtes, der Domestikation und Kastration. - Ztschr. Zellf. mikr. Anat.., 23 p. 677.

SCHREIBER B. 1937, Ricerche sulla spermatogenesi accelerata dell'Anguilla. - Arch. Zool. Ital., 24.

SCHREIBER B., ANGELETTI S. 1940, Rhytmic increase and decresse of nuclear volume of the hepatic cell of the Carp, Cyprinus Carpio var. specularis. - Anat. Record, 76 p. 431.

SCHREIBER G. 1934, Lapplicazione delle leggi d'azione degli ormoni alla metamorfosi degli Anuri. - Arch. Zool. Ital. XX p. 325.

- 1937, La definizione degli stadi della metamorfosi del Bufo. - Rend. R. Accad. Naz. Lincei, vol. XXV p. 342.

SCHREIBER G, ROMANO M. 1937, Contributi allo studio dei fattori della metamorfosi degli Anuri. - Boll. Soc. It. Biol. Sper. XII, p. 623.

WERMEL E, IGNATJEWA Z. 1932, Studien ueber Zellengrösse und Zellenwachstum. 1 Mitteilung: ueber die Grössenvariabilität der Zellkerne verschiedener Gewebearten. - Z. Zellf. 16.

WERMEL E, IGNATJEWA Z. 1932, II Mitt. Ueber Veränderung der Zellgrösse bei Gewebeexplantation. - Z. Zellf. 16.

- 1933, III Mitt. Ueber Veränderung der Kerngrösse bei Gewebeexplantation. - Z. Zellf., 17. 
WERMEL E. 1933, IV Mitt. ueber Dimensionen der Samenzellen u. s. w. der Seidenraupen. - Z. Zellf. 17.

WERMEL E., PORTUGALOW W. W. 1933, V Mitt. ueber die Wirkung von Prolan auf die Zellengrösse. - Z. Zellf. 20. p. 36.

IVERMEL E, IGNATJEWA Z. 1933, VI Mitt. Weitere Beobachtungen ueber den Einfluss der Gifte auf die Kerngrösse der Leberzellen. - Z. Zellf. 20. p. 43.

WERMEL E., SCHERSCHULSKAYA L. W. 1933, VII Mitt. Ueber die Grösse der bösartigen Zellen und ihre Variabilität. - Z. Zell. 20. p. 54.

- 1933, VIII Mitt. Ueber proportionelles (rhytmisches) Wachstum. - Z. Zellf. 20 p. 459.

WERMEL E. 1933, IX Mitt. Das Gesetz der Beständigkeit minimaler Zellengrösse. - Z. Zellf. 20. p. 467. 